\title{
鉄およびたん白欠乏が成長期ラットのへム 合成系酵素におよぼす影響
}

\author{
浦田郡平, 近 藤 雅雄, 木村秀子 \\ 長谷川葉子, 鉿木妙子, 梶本 雅 俊

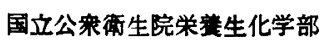 \\ Effect of Iron and Protein Deficiency on ALA-Dehydratase \\ ALA-Synthetase and Heme-Synthetase Activities \\ of Growing Rats \\ Gumpei URATA, Masao KONDO, Hideko KIMURA, \\ Yoko HASEGAWA, Taeko SUZUKI, Masatoshi KAJIMOTO \\ Department of Nutrition and Biochemistry, Institute of Public Health, Minato-ku, Tokyo
}

In this paper, the effect of iron deficiency on the hematopoietic function of rats was studied under experimental conditions identical with those described in the preceding report ( $\operatorname{Part} 1$ ). Specimens of peripheral blood, bone marrow and liver from rats in the four groups that had been maintained on diets varying in iron and casein contents were assayed for activities of three of the eight heme synthetic enzymes, i.e. ALA synthetase (ALA-S), ALA dehydratase (ALA-D) and heme synthetase (Heme-S). The first two enzymes are known to take part in the first and second limiting steps in the heme biosynthesis pathway and the latter, the final step. The results were as follows: (1) In the $20 \%$ casein group, the ALA-S activity in bone marrow was lowered and the ALA-C activity in peripheral blood increased during the iron deficient stage. The ALA-S activity in bone marrow returned to a control level while the blood ALA-D activity showed a further elevation during the subsequent recovery stage with dietary iron supplementation. In contrast, both ALA-S and ALA-D activity in the 5\% casein group did not show any appreciable difference from the control levels, during the iron deficient stage. However, subsequent replacement of the diet with a $20 \%$ casein was followed by a sharp increase of the activity of these enzymes. The findings indicated that protein intake had a greater influence than iron intake in this respect in rats under low-protein nutrition, as far as ALA-S and ALA-D activities were concerned. (2) Heme-S activity displayed responses distinct from those observed with the foregoing two enzymes. Both the $5 \%$ and $20 \%$-casein diet groups exhibited elevation of this enzyme to essentially the same degree during the iron-deficient stage, with a complete restoration to the control level, in both groups, following resupplementation of feed with iron.

In the (5\% casein) group, only the readministration of iron feed was effective for this recovery of the enzyme while replacement with (20\% casein) had little or no effect.

From these experimental findings, it is evident that the effects of iron deficiency in respect of changes in ALA-S and ALA-D activities, appear only in those animals maintained on a $20 \%$ casein diet; thus remarkably consistent with the body weight and hematological changes seen in this diet group of rats in the previous study. Heme-S activity, on the other hand, seems to have a particular responding pattern to iron deficiency which is considered to occur in direct association with iron metabolism and irrelevant to protein nutrition.

(Received August 14, 1980)

\footnotetext{
†铁およびたん白欠乏が成長期ラットの血色素合成

におよぼす影復（第2報）

Effect of Iron and Protein Deficiency of

Hematopoiesis in Growing Rats (Part 2)

于108 東京都港区白金台 4-6-1
} 
52

前報12 では鉄欠乏の影響を $20 \%$ と $5 \%$ カぜイン 食 2 種類のたん白摄取をさせた成長期ラットについて調 へた結果，体重曲線では対照との間に差を認めなかった が，血液へモグロビン (Hb) 值, ヘマトクリット (Ht) 值などは $20 \%$ カゼイン摄取群にのみ鉄欠乏の影䈏があ らわれ，明白な低下を示したにるかかわらず，5\%カぜ イン群では対照との間に差が見られないといら現象を報 告した。

本報ではこの両群における鉄欠乏の影整のちがいが造 血機粠に対しても同槏な变動を起こしているのか否かを 検討するため, 骨能, 䀒においてへム生合成の取初の律 速段㳻をつかさどるデルタフミノレフリン酸合成醅菜 $\delta$-Aminolevulinic Acid Synthetase=ALA-S (EC 2.

3. 1. 37) と最終段階の 2 価鉄を Proto IX に㨉入させ るへム合成酵素 (Heme Synthetase=Heme-S (EC 4. 99. 1. 1), ならびに末枌血, 骨验, 肝からは取初のピロ 一ル合成を触媒するデルタフミノレブリン酸脱水醅亲 ( $\delta$-ALA Dehydratase $=$ ALA-D (EC 4.2.1.24)1)の 三つの酵素について検討した。

\section{実 験 方 法}

\section{1. 実験材料之諸成分含息測定法}

動物は前報》〕におけるット群をそのまま用いた。 各個体から採り出した末梢血, 肝䁍, 骨㖪について次頁 でのべる方法で3醇素の活性を测定した。基質として用 いた化合物のうち, ${ }^{14} \mathrm{C}$-succinyl-Co-A は市販の 1,4${ }^{14} \mathrm{C}$-succinic anhydride ( $\mathrm{NEN}$ 社, $10 \mathrm{mCi} / \mathrm{mM}$ ) と free Co A (拹和酸酵) とから通常の方法 ${ }^{2)}$ を用いて合成し た。 ${ }^{59} \mathrm{Fe}^{3+}$ は市肘の ${ }^{59} \mathrm{FeCl}_{3}$ (RCC 社, $18 \mathrm{mCi} / \mathrm{mgFe}$ ) を水で一定に希釈して用いた。プロトポルフィリンは Grinstein の方法 ${ }^{3)}$ に従ってヒト末梢血から dimethy ester として再結晶, 使用前に氷冷 $10 \mathrm{~N}-\mathrm{HCl}$ 中で 1 夜 処理して free 化したのち中和して用いた。たん白質泿 度の測定は Lowry らいの方法によった。その他，一般 試薬, 器具は前報と同じすのを用いた。

赤血球中プロトポルフィリン (PP) とコブロボルフィ リン（CP）の定量は，上記へパリン採血を $10 \mathrm{ml}$ とり， その血球を生理的食塩水で 2 回洗浄したものについて Falk-Dresel $5^{5) 6)}$ の原法を実施した。定量結果は porphyrin $\mu \mathrm{g} / 10 \mathrm{ml} \mathrm{RBC}$ として麦示した。

網赤血球数の測定法は前報に記載した。

\section{2. 䤖素液の調製と活性測定法}

ALA-S : ラット各 1 匹から採り出した 2 本の大腿骨 の両骨端を切り落し, 中央部の骨㩆を, 一端から氷冷生 理的食塩水を圧入しながら洗い出してあつめ，全量を生 理的食塩水で 2 回遠沈洗浄する。全沈股に $2.0 \mathrm{ml}$ 氷冷 水を加え, 10 分間溶血したのち $11.5 \% \mathrm{KCl} 0.2 \mathrm{ml}$ を

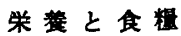

加光て等張にもどし，このものの $10^{4} \times g ， 30$ 分薏心の 沈殿（上清は次項の ALA-D 湘定用に用いる）を 1.15 $\% \mathrm{KCl}(2 \mathrm{mM}-\mathrm{KPB}, \mathrm{pH} 7.5)$ Kて 2 回洗浄したのち, 同液に揫濁して終量 $3.0 \mathrm{ml}$ に合わせ，ALA-S 測定用 の醭来液として用いる。すなわち， $0.3 \mathrm{ml}$ K $0.5 \mathrm{mM}$ ${ }^{14} \mathrm{C}$-succinyl Co-A $0.05 \mathrm{ml} \quad(0.5 \mu \mathrm{Ci}), 1 \mathrm{M}$-glycine (2 mM-pyridoxal-5'-phosphate) $\quad 0.05 \mathrm{ml}, \quad 10 \mathrm{~mm}$ EDTA $0.05 \mathrm{ml}, 0.5 \mathrm{M}-\mathrm{NaPB}$ (pH 7.5) $0.05 \mathrm{ml}$ を加 え, 釉量 $0.5 \mathrm{ml}$ で $37^{\circ} \mathrm{C}, 30$ 分インキュベートしたの ち, $0.3 \mathrm{M}$-TCA $2.0 \mathrm{ml}$ を加え反応を停止する。遠沈上 清に, 沈殿の $0.3 \mathrm{M}-\mathrm{TCA} 2.0 \mathrm{~m} l$ 洗液を加え, 全量に つきAoki らの原法”に準じた著者らの方法" ALA を定量的に精製純化し，最後にジオキサン系シン チレータ中で ${ }^{14} \mathrm{C}$-放射活性を測定した。次に，採り出し たラット新鮮肝 $1.0 \mathrm{~g}$ を薄刃の刃物で細片化したのち, $10 \mathrm{ml}$ の $0.25 \mathrm{M}$-sucrose (pH 8.0) でホモジナイズし, 以下一般の Schneizer-Hogeboom 法9 に準した著者ら の方法")でミトュンドリフを調製，全量を $0.2 \mathrm{mM}$ pyridoxal-5'-phosphate, $1 \mathrm{~mm}$-EDTA, $0.1 \mathrm{M}$-glycine, $0.05 \mathrm{M}-\mathrm{NaPB}(\mathrm{pH} 7.5)$ に怒濁して $3.0 \mathrm{ml}$ K合わせ たものを醉素液として用い，以下骨淔 ALA-S 液の場合 とまったく同じ操作で ALA-S 活性を湘定した。得られ た活性度は pmol ALA/1 mg protein/30 min で表示し た。

なお, 肝ホモジネートの $10^{6} \times g, 10$ 分の遠沈上清は 次項の ALA-D 活性测定用酵素液として用いた。

ALA-D : Granick らの方法 ${ }^{10)}$ に順じて以下のよらに 行なった。ラットをエーテル麻醉下で腋下血管を切断し ヘバリン採血する方法で得られた末梢血 $0.05 \mathrm{ml} 0.4$ $\mathrm{m} l$ の冷水を加えて 10 分間溶血したのち、これに ALAGSH 混液 (0.05 M-ALA, 0.1 M-GSH, 0.5 M-NaPB (pH 6.8) 3 者の混合液) $0.05 \mathrm{ml}$ を加光䅂量 $0.5 \mathrm{ml}$ で $37^{\circ} \mathrm{C}, 60$ 分間インキュベートしたのち, $1 \mathrm{M}-\mathrm{TCA}$ $0.5 \mathrm{ml}$ 加えて反応を停止する。この遠沈上清について Granick らの原法 ${ }^{10}$ )に従って, 生成した PBG (porphobilinogen) 量を測定した。なお，前記ホモジネートおよ び骨鰱溶血液の $10^{4} \times g, 10$ 分の上清についてるまった く同じ操作で ALA-D 活性を測定した。活性度は肝, 骨 髄については nmol PBG/1 mg protein $/ 60 \mathrm{~min}$ で表示 し, 末梢血の揚合は洗浄赤血球 $1 \mathrm{~m} l$ あたりに換算して, $\mathrm{nmol} \mathrm{PBG} / 1 \mathrm{~m} l \mathrm{PVE} / 60 \mathrm{~min}$ で表示した。

Heme-S : Sawada らの方法 ${ }^{11)} に$ 準じて以下のように 実施した。ALA-S の項で骨檤または肝から調製した ALA 测定用醭素液の残部をそのまま用い, その $0.5 \mathrm{ml}$ K $200 \mu \mathrm{M}$-protoporphyrin (0.1 M- $\mathrm{KHCO}_{3}$ 中 $\left.\mathrm{pH} 7.5\right)$ $0.1 \mathrm{ml}, 200 \mu \mathrm{M}-\mathrm{FeSO}, 0.1 \mathrm{ml},{ }^{50} \mathrm{FeCl}_{3}$ 水溶液 $0.05 \mathrm{ml}$ $(1 \mu \mathrm{Ci}), 0.5 \mathrm{M}$-Tris 業液 ( $\mathrm{pH} 8.0) 0.2 \mathrm{ml}, 0.4 \mathrm{M}$ - 


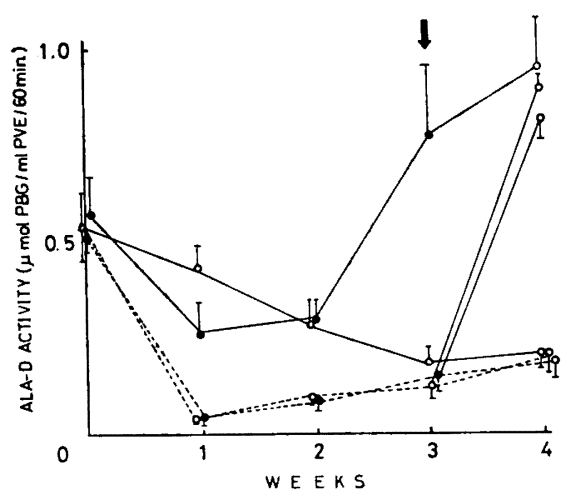

Fig. 1. Effect of dietary protein level and iron deficiency on blood ALA-D activity of rats.

The meaning of marks and lines are as follows. $-0-0,20 \%$, casein, control; - - - $20 \%$ casein, iron deficient; - - $-20 \%$ casein, iron deficient, changed to $20 \%$ casein, control;

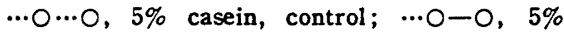
casein, control, changed to $20 \%$ casein, control ; $\cdots \bullet \cdot 5 \%$ casein, iron deficient; $\cdots \bullet \cdots 0$, $5 \%$ casein, iron deficient, changed to $5 \%$ casein, control; $\cdots-0,5 \%$ casein, iron deficient, changed to $20 \%$ casein, control. The vertical lines represent standard deviation mean. The arrow indicates the time of dietary change.

GSH $0.1 \mathrm{ml}$ を加え, 終量 $1.05 \mathrm{ml}$ で, 空気中 $37^{\circ} \mathrm{C}, 2$ 時間インキニベートしたのち, carrier $\mathrm{Hb}$ (ヒトの洗浄 末梢血球を 2 倍量の水で容血したすの) $1.0 \mathrm{ml}$ とアセト ン $10 \mathrm{ml}$ を順次加え, 生成した沈股を遠心であつめ, 氷 酢酸：フセトン混夜 $(1: 4) 10 \mathrm{ml}$ で2 回へムを抽出し て台わせ, これに少量の $\mathrm{NaCl}$ 粉末を加え, へミンの結 晶が出始めるまで減压浐縮し，1夜放膡して結晶の析出 を完成させたのち，これを遠心であつめ，沈殿を $1 \%$ $\mathrm{HCl}$ で 2 回，水で 1 回洗浄したのち全量を $2 \mathrm{ml}$ の $10 \%$ $\mathrm{NH}_{4} \mathrm{OH}$ に溶解し, このらち $1.0 \mathrm{ml}$ を $\gamma$-counter にか けて ${ }^{59} \mathrm{Fe}$ 一へムの ${ }^{59} \mathrm{Fe}$ 放射活性を即定し, $0.2 \mathrm{ml}$ K 3 $\% \mathrm{KCN} 0.1 \mathrm{ml}$ を加えたあと一定量の水で希积して

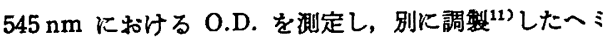
ンの検量直線を用いてへミン量を測定する。

活性は pmol ${ }^{59} \mathrm{Fe}$-heme $/ 1 \mathrm{mg}$ protein $/ 120 \mathrm{~min}$ で表 示した。

\section{実 験 結 果}

\section{ALA-D 活性}

Fig. 1 飞末梢血液中の ALA-D 活性の変動を示した。 $5 \%$ カセイン群, $20 \%$ カゼイン群とすに, 成辰にとすな
って低下したが，铁欠乏の影鳖は，20\% 群にたいして のみ認められた。すなわち，对照にくらべて1週目でや や低下したのち，2週目から急做に上昇し，そのあとの 鉄投与による回復期に入ってさらに上昇した。これに対 して 5 \%群では铁欠乏の影㹕はまったく見られず，また 鉄再投与によっても变化はなかった。しかし，この群に 鉄と $20 \%$ カゼイン投与による回復を行ならと, 対照 群, 鉄欠乏群とすに 20\% カゼイン铁欠乏群の敇投与に よる回復群と同じ値にまで急上昇した。

前報31)の Fig. 6 に網赤血球数の变動を示したが，20 \%鉄欠乏群においては対照群にくらべて1週目でやや低 下したのち，2週目が上昇に転じ，铁投与による回復期 では約 6 倍の高值を示した。5\%群では，鉄欠乏群，対 照群とすに差は見られなかったが，鉄と $20 \%$ カゼイン 投与による回復群ではそれぞれ約 10 倍に上㫒した。

Fig. 1 と前報 ${ }^{11}$ Fig. 6 を並べて見ると，末梢血中 ALA-D 活性の変動之網赤血球数の变動が $20 \%$ 鉄欠群 における 3 週目の一点を除き完全に一致しているのがわ かる。

Table 1 に骨面と肝瞒における ALA-D 活珄の变動 を示した。それによると，骨铕中の ALA-D 活性は 5 ， 20\%両群とすに鉄欠乏群のほらが高い傾向を示し，鉄投 与による回復，および $20 \%$ カゼイン投与による回復群 で上㫒の㑯向を示すなど，末梢血中の活性変動と同様の 傾向を示した。肝の ALA-D は末桶血，骨蹃にくらべて 数倍の高活性を示したが，たん白質摄取の变動，铁欠乏 のいずれによっても，全実験期間を通じて有意の変化が 見られなかった。

\section{ALA-S 活性}

Table 2 飞測定結果を示した。骨鲔中 ALA-S 活性は $20 \%$ の鉄欠乏群において低下し，鉄投与による回復で 0 time 値にもどった。 $5 \%$ 群において対照群と鉄欠乏 群の間に差は見られなかったが，回復期においては鉄と $20 \%$ カゼイン投与によって約 1.8 倍の上㫒を示し, 鉄 投与だけではほとんど反応を示さなかった。

䀒 ALA-S 活性（Table 2) は一般に测定値が低く， 両群とも次乏では骨殖 ALA-S と同様の变動傾向を示 したものの，明白な結論は得られなかった。

\section{Heme-S 活性}

Table 3 火測定結果を示した。骨䯣 Heme-S では両 群とも鉄欠乏期に抌いて有意に上昇し，次の回復期にお いて，鉄投与によってのみ対照値にもどった。

䀒 Heme-S 活性は両群ともに, 鉄欠乏および回復に ついて, 対照群との間に有意差が諗められなかった。

\section{4. 赤血球中遊淮ポルフィリン体典}

Table 4 に赤血球中遊離ボルフィリン体の定量結果を 示した。これによると、まずプロトポルフィリンについ 
Table 1. Effect of iron and protein deficiency on ALA-D activity in bone marrow and liver.

\begin{tabular}{llccc}
\hline \hline \multirow{2}{*}{$\begin{array}{c}\text { Casein } \\
(\%)\end{array}$} & \multicolumn{1}{c}{ Groups } & $\begin{array}{c}\text { Periods } \\
\text { (weeks) }\end{array}$ & \multicolumn{2}{c}{ ALA-D activity (nmol PBG/1 mgp/60 min) } \\
\cline { 5 - 5 } & Start & 0 & $4.22 \pm 0.48$ & Bone marrow \\
\hline 20 & Control & 3 & $1.85 \pm 1.45$ & $13.2 \pm 1.60$ \\
& Iron deficient & 3 & $2.33 \pm 0.95$ & $12.9 \pm 1.55$ \\
& Control & 4 & $1.05 \pm 0.27$ & $13.2 \pm 1.56$ \\
& Recovery by iron & 1 & $2.94 \pm 1.54$ & $13.9 \pm 1.24$ \\
\hline 5 & Control & 3 & $1.85 \pm 0.70$ & $13.3 \pm 3.77$ \\
& Iron deficient & 3 & $2.40 \pm 1.82$ & $12.3 \pm 2.16$ \\
& Control & 4 & $3.91 \pm 2.12$ & $13.6 \pm 1.42$ \\
& Recovery by iron & 1 & $2.59 \pm 1.18$ & $12.0 \pm 1.25$ \\
& Recovery by 20\% casein & 1 & $4.67 \pm 0.86$ & $14.9 \pm 1.04$ \\
& Recovery by iron and 20\% casein & 1 & $3.61 \pm 1.27$ & $13.8 \pm 1.80$ \\
\hline \hline
\end{tabular}

Values represent mean \pm S.D. of 5 rats per group. The procedure for determination of activity was described in the text.

Table 2. Effect of iron and protein deficiency ALA-S activity in bone marrow and liver.

\begin{tabular}{llccc}
\hline \multirow{2}{*}{$\begin{array}{c}\text { Casein } \\
(\%)\end{array}$} & \multicolumn{1}{c}{ Groups } & $\begin{array}{c}\text { Periods } \\
\text { (weeks) }\end{array}$ & \multicolumn{2}{c}{ ALA-S activity (pmol ALA/1 mgp/30 min) } \\
\cline { 5 - 5 } & Start & 0 & $664 \pm 201.0$ & Bone marrow \\
\hline 20 & Control & 3 & $425 \pm 170.0$ & $3.4 \pm 4.56$ \\
& Iron deficient & 3 & $296 \pm 53.0$ & $5.0 \pm 1.00$ \\
& Control & 4 & $679 \pm 211.0$ & $3.6 \pm 1.52$ \\
& Recovery by iron & 1 & $652 \pm 228.0$ & $5.2 \pm 3.56$ \\
& Control & 3 & $417 \pm 152.0$ & $2.6 \pm 1.14$ \\
\hline \multirow{2}{*}{5} & Iron deficient & 3 & $440 \pm 70.2$ & $7.4 \pm 1.52$ \\
& Control & 4 & $428 \pm 162.0$ & N. D. \\
& Recovery by iron & 1 & $528 \pm 173.0$ & $9.0 \pm 5.83$ \\
& Recovery by 20\% casein & 1 & $822 \pm 100.0$ & N. D. \\
& Recovery iron and $20 \%$ casein & 1 & $778 \pm 222.0$ & $5.4 \pm 2.60$ \\
& & & $2.2 \pm 1.30$ \\
\hline
\end{tabular}

Values represent mean \pm S.D. of 5 rats per group. The procedure for determination of activity was described in the text.

ては, $20 \%$ 群, $5 \%$ 群とすに対照群においては成长にし たがって低下し，4䢙目では出発値の 30 50\% を示し た。

これにくらべて鉄欠乏においては，20\% 群でさらに 低下，铁回復 1 週目でやや上㫒を示した。5\%群では低 下がややおそくなったように見えたが，铁投与による回 復 1 週目で一転急低下した。またこの群では鉄と $20 \%$ カゼインの同時投与による回復 1 週目で逆に急上㫒し，
出発値に近ついた。

次にコブロポルフィリンについては, 20\% 群の対照群 で成長にともなって上㫒し，铁欠乏ではこの上界が見ら れなかった。また $5 \%$ 群の対照群では成長にともなって 急上早したのち，急低下するといら潄しい変化を示した が，铁欠乏群ですほぼ同じバターンを示し，低下したあ とは，鉄と 20\%カゼインKよる回復1週後ですほぼ不 変であった。 
Table 3. Effect of iron and protein deficiency on Heme-S activity in bone marrow and liver.

\begin{tabular}{llccc}
\hline \hline \multirow{2}{*}{$\begin{array}{c}\text { Casein } \\
(\%)\end{array}$} & \multicolumn{1}{c}{ Groups } & $\begin{array}{c}\text { Periods } \\
\text { (weeks) }\end{array}$ & \multicolumn{2}{c}{ Heme-S activity (pmol ${ }^{59} \mathrm{Fe} \mathrm{Heme/1} \mathrm{mgp/2} \mathrm{hrs)}$} \\
\cline { 5 - 5 } & Start & 0 & $1.83 \pm 0.52$ & Bone marrow \\
\hline 20 & Control & 3 & $1.28 \pm 0.19$ & $0.68 \pm 0.21$ \\
& Iron deficient & 3 & $1.95 \pm 0.29$ & $0.32 \pm 0.05$ \\
& Control & 4 & $1.35 \pm 0.39$ & $0.50 \pm 0.10$ \\
& Recovery by iron & 1 & $1.41 \pm 0.30$ & $0.49 \pm 0.06$ \\
& Control & 3 & $1.45 \pm 0.47$ & $0.41 \pm 0.11$ \\
5 & Iron deficient & 3 & $2.05 \pm 0.71$ & $0.40 \pm 0.11$ \\
& Control & 4 & $1.71 \pm 0.91$ & $0.52 \pm 0.13$ \\
& Recovery by iron & 1 & $1.46 \pm 0.31$ & $0.41 \pm 0.04$ \\
& Recovery by 20\% casein & 1 & $1.78 \pm 0.23$ & $0.34 \pm 0.07$ \\
& Recovery by iron and 20\% casein & 1 & $1.53 \pm 0.32$ & $0.47 \pm 0.15$ \\
\hline \hline
\end{tabular}

Values represent mean \pm S.D. of 5 rats per group. The procedure for determination activity was described in the text.

Table 4. Effect of iron and protein deficiency in blood porphyrins content.

\begin{tabular}{llccc}
\hline $\begin{array}{c}\text { Casein } \\
(\%)\end{array}$ & \multicolumn{1}{c}{ Groups } & $\begin{array}{c}\text { Periods } \\
(\text { weeks })\end{array}$ & $\begin{array}{c}\text { Coproporphyrin } \\
(\mu \mathrm{g} / 10 \mathrm{~m} l \mathrm{RBC})\end{array}$ & $\begin{array}{c}\text { Protoporphyrin } \\
(\mu \mathrm{g} / 10 \mathrm{~m} l \mathrm{RBC})\end{array}$ \\
\hline \multirow{2}{*}{20} & Start & 0 & 0.42 & 11.73 \\
& Control & 3 & 0.72 & 9.46 \\
& Iron deficient & 3 & 0.59 & 6.15 \\
& Control & 4 & 1.40 & 4.09 \\
& Recovery by iron & 1 & 0.41 & 6.79 \\
\hline \multirow{2}{*}{5} & Control & 3 & 1.60 & 4.39 \\
& Iron deficient & 3 & 2.15 & 6.33 \\
& Control & 4 & 0.31 & 5.53 \\
& Recovery by iron & 1 & 0.20 & 3.03 \\
& Recovery by 20\% casein & 1 & 0.53 & 10.71 \\
& Recovery by iron and $20 \%$ casein & 1 & 0.46 & 9.20 \\
\hline
\end{tabular}

The peripheral blood from each group pooled, from which $\mathrm{RBC}$ was washed twice with $0.9 \% \mathrm{NaCl}$ and subjected to the determination of protoporphyrin and coproporphyrin content according to FalkDresel method.

\section{考察}

1) ALA-D について 骨䯣および末梢血中の本酥素 は﨎秏期の初めに最高活性を示し，以後成長にともなっ て急雄に低下していくとい5生理的性質をすってい

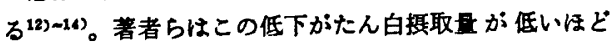
早期に，かつ急制に起こることをすでに報告12) し，今回 も同じ結果を得た。Fig. 1 が $20 \%$ の鉄欠乏群では 2 週
目から上昇傾向を示し，同時に測定した絧赤血球数変野 がよく一致した。このことと，一般に血中 ALA-D 活性 が網赤血球数に注ぼ比例するといら既定事実(19)16)とから 本実㯺では 20\% カセイン群では铁欠乏による造血の刺 数が起こっていることが吢づけられる。

しかし，Fig. 1 および前報11) Fig. 6 の示すよらに， $5 \%$ \%ガイン群のたん白による回復における活性の急上 㫒は鉄再投与の有無によるよりす，むしろ高たん白食へ 
56

の転換を主体として起こっており，赤血球産生のみなら ず，ALA-D 活性の制御，おそらく醅素たん白自身の生 産調節が，鉄代謝たけでなく，たん白貿代謝によっても 行なわれることを示唆していると考えられる。なお， ラ ット末梢血に拈ける鉄欠乏と鉄再投与に拈ける ALA-D 活性の変動については, Labbe ら ${ }^{17)}$ がすでにまったく 同じ結果を報告している。

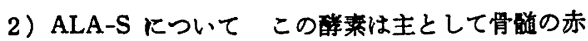
芽細胞に含まれ，肝にる弱く存在する。ALA-S 活性は 生後直後から成辰期にわたり徐々に上年することがわか っている(2)。本実験に打ける鉄欠乏群のうち，20\%カぜ イン群では開始後 3 週目に一度低下したが, 鉄回復 1 週 目で開始值にすどったのに対し，5\%カゼイン群では铁 欠乏期間中はやや低下したものの，回復期では対照值の 約 1.5 倍に上早しており，しかむこの上㫒が鉄の再投与 によってではなく，20\% カゼインに切りかえたたけけで起

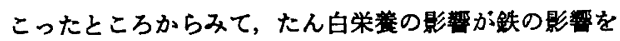
上回ったと見られる。Table 2 によると $20 \%$ カゼイン 鉄欠乏群において，骨髄 ALA-S 活性が低下することを 示している。これまでの報告では，同様の実験条件下に 低下 ${ }^{18)}$ と上䄯 ${ }^{19}$ という相反する結果が得られており，ど ららが真の事実であるかについては，これまで鉛中吂30) やボルフィリン症など20) のへム合成異常において, ALA-S と ALA-D の活性変動バターンがしばしば密接 に連動していることが知られており，鉄欠乏においても 同様な動きが起こると推定してみると,ALA-SはFig. 1 に示した ALA-D のよらに一度低下してから上㫒に転 ずるといらバターンをとってむよいことになり，これま での報告者がこのらちの低下の時期と上昇の時期の一点 ずつをとらえていたのかるしれないといら可能性が生ず る。ヒトの铁欠乏性筫血での測定報告では，いまのとこ

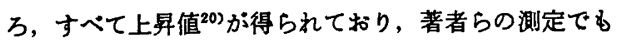
わずかに上昇的である ${ }^{21)}$ 。

3) Heme-S について Table 3 によれば制欠乏に 対する Heme-S の応答は ALA-S, ALA-D の場合とは 逆のパターンを示すことがわかる。そして鉄欠そ時の活 性上界が回復期において対照値にもどるのは鉄再投与に よってのみ起こっており，たん白再投与では無効であっ たことから，本䤃素は鉄の欠乏と再投与に対して ALAD, ALA-S よりも直接的な応答をすることは明らかで ある。ヒトの鉄欠乏性貧血では，いまのところ，本酵素 活性は変わらないといら報告22が多い。

以上，3酵素のそれぞれについて，活性変動を観察し たが，つぎに、これらをまとめ鉄欠乏時におけける造血酵 妻の全体的変動として考察すると, $20 \%$ カセイン群につ いては, 鉄欠乏の影皟は 1 週目で現われはじめ, 末梢血中 および骨稙の ALA-D と, おそらく ALA-S が低下し,

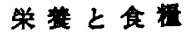

ついでこの両䤃案は上年に転じて刺溦状態となり，これ が铁投与による回復期に入っても繀き，その後さらに一 定期間くすのと考えられる。ALA-S とALA-Dのこ のよらな動きにくらへると，骨䯠 Heme-S の䡃きは铁 欠乏で上昇し，回復 1 週目で完全に対照値にもどり，鉄 の有無にたいして直接的に応答することを示した。この ような本醅素活性の応答の引き金になる因子が鉄欠乏の ぞの段階に存在するであろらかについて推定してみる と，ます詝蔵鉄の動きについて前報"11 の Table 3 の結 果をみると，血清鉄および肝鉄含量，脾鉄含量の動きは $5 \%$ 群と $20 \%$ 群ともに共通点が多い。しかし末桶血中 の $\mathrm{Hb}$ 含量, 網赤血球数は $5 \%$ 群では鉄欠乏の影第がま ったく見られない。

以上の事実からラット铁欠乏における本醭素の上畀は

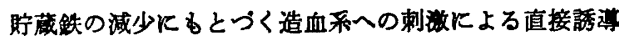
と考劣るよりる，むしろ，腸管からの鉄吸収の激減を取 初の刺做として開始される鉄吸収の活性增大到 25$)$ 飞直 結して起こる本醭素の誘導現象と考えるのが妥当のよう に思われる。20\% カせイン群におけるこれらの醉素 動の大部分は前報 ${ }^{31}$ )における同群の血色素量の動きとよ く呼応している。また Table 4に記载した血中ボルフィ リン旦の変動をみると,プロトポルフィリンについては $5 \%$ カゼイン, $20 \%$ カゼイン両群とる铁欠乏で低下, その後鉄やたん白摂取の回復によって上昇に転じている ことから鉄欠乏期が続けば上記 ALA-D, ALA-S 活性同 様上昇に転ずる時期があると推定すれば，これまでの報 告と矛盾しない。またコブロボルフィリンについてはラ ットの成長にとるなって上昇する時期があることがわか ったが,これが鉄欠乏によってどのように変動するかに ついては確実な結論は得られなかった。

つぎに $5 \%$ \%ガイン群について考察する。鉄欠乏によ って ALA-D, ALA-S の変動はまったく見られなかっ た。これを前報点)の同じラット群( $5 \%$ カゼイン)につい ての結果と合わせて見ると, 低たん白摄取ラットでは鉄 欠乏によって体重や Hb 量などのいわゆる外面レベルで は差が起こらないこととよく符合する。ところが Heme$\mathrm{S}$ 活性だけ铁欠乏に対応して上䒜し，これが鉄再投与 によってのみ元にもどることは上にのべた。さらにこの 群の血中ボルフィリン值を見ると $20 \%$ 群よりる反応が 激しく，鉄欠乏によって急上昇した。一般に鉄欠乏時に は腸管からの鉄の吸収やへムの取り込みが促進されるこ

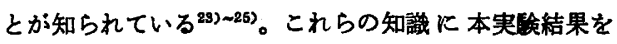
加えてみると，鉄の代謝に限って以下のような推定にな る。鉄が欠乏すればたん白栄㢣状態にかかわらず釷の吸 収, 輸送, 一ムの組み入れなどの全過程について式速な

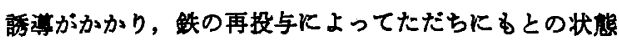
にもどるといら䧟応機構が存在する。 


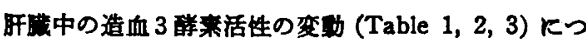

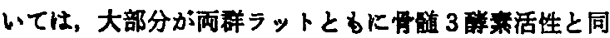
栚の傾向を示したるのの, 活性度, 变動幅とすに低く, 確実な結論にはいたらなかった。

以上の考察は，今後さらに長期間にわたって肝，骨稙

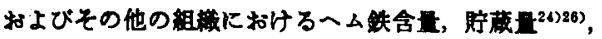
血清铁年などの動き（前報参照）ととすに詳細に検索を 進めなければならない。

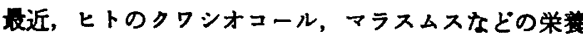
障害において必ずしす盆血が高度でない者が見いたさされ

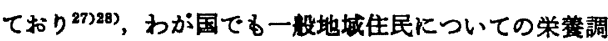
㚗において低たん白摄取と㣱血の程度が必ずしも平行し ないという報告29)がある。これらの現象はヒトの栄飬摄 取バターンの複雑な变化が関与しており，本研究におけ ろ $5 \%$ カゼイン群のよらな単純な系で得られた実険結果 をそのままあてはめることはできないが，少なくともと トにす同じような看応の機能が存在するのではないかと いら推定の根拠を提示するるのである。

要約

本報では铁欠乏がラットのへム合成醉来活性に及ぼす 影简をしらべた。すなわち, 前報31〉をったく同じ実験条 件下に拉けるラットのそれぞれから採り出した末梢血， 骨饂，および肝について，人ム合成采酵素8種のらちか ら ALA-S (ALA synthetase), ALA-D (ALA Dehydratase), Heme-S (Heme Synthetase) の 3 種を選び 活性を测定した。前 2 者はへム生合成の初期段階を，後 者は最後の段階を律速する醭素である。

1） $20 \%$ カゼイン群では，鉄欠乏によって骨政有の ALA-S 活性が低下, 末桶血の ALA-D 活性が上㫒し, 失の再投与による回復期において ALA-S 活性は対照值 にもどったが, ALA-D 活性はさらに上早した。一方, $5 \%$ \%゙イン群では，铁欠間中は ALA-S, ALA-D 活性ともに対照值との間にまったく差が起こらなかっ た。しかし，このあとたん白を $5 \%$ カゼインから $20 \%$ カゼインに切りかえたところ両醭絜活性とるに急上㫒 し, ALA-S, ALA-D 活性に関する限り，5\%カゼイン

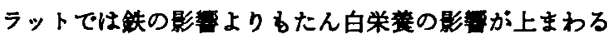
ことを示した。

2) Heme-S 活性は前 2 醅素とは異なる対応を示し た。すなわち鉄欠乏によって 20\%，5％カセイン群, とるに同程度に上昇し，鉄再投与によって完全に対照值 にもどった。この回復現象は $5 \%$ カゼイン群においては 铁の再投与のみが有効であり, $20 \%$ カゼイン食への切り かえは無効であった。

3）末梢血 ALA-D 活性は網赤血球数とほ活比例し た。
4) 肝の ALA-S, ALA-D, Heme-S 活性に対する铁 欠乏の影裙は少なかった。

以上から鉄欠乏の影整は, ALA-S, ALA-D 活性に咸 する限り，20\% カゼイン群にのみ出現することがわか りここれは前報における同ラット群の示した体車, 血液 性状などの変化とよく一致する。しかし, Heme-S 活性 の変動は，たん白栄塑と無関係に，铁の代謝と直結して 起こると推定される。

\section{文献}

1) Tschudy, D.P. and Lamon, J.M. : Porphyrin Metabolism and the Porphyrias. Metabolic Control and Disease (Bordy, P.K. and Rosenberd, C.E., eds.), p. 939 (1980), Saunders (Philadelphia)

2) Simon, E.J. and Shemia, D. : J. Am. Chem. Soc., 75, 2520 (1953)

3) Grinstein, M. : J. Biol. Chem., 167, 515 (1947)

4) Lowry, O.H., Rosebrough, N.J., Farr, A.L. and Randalb, R.J. : J. Biol. Chem., 193, 265 (1951)

5) Dresel, E.I.B. and Falk, J.E. : Biochem. J., 63, 72 (1956)

6）浦田郡平：臨床㭘查技術全書（石井暢編集，Vol. 6), p. 357 (1975), 医学書院 (東京)

7) Aoki, Y., Takaku, F., Urata, G. and Wada, O. : J. Clin. Invest., 53(5), 1326 (1974)

8）浦田郡平, 近藤雅雄, 清水純孝 : 文部省特定研究 「難病」班報告青（昭和52年度)，P. 534 (1978)

9) Hogeboom, G.H. : Methods in Enzymology (Colowick, S.P. \& Kaplan, N.O., eds., Vol. 1), p. 16 (1955), Academic Press, Inc. (New York)

10) Granick, S. and Mauzerall, D. : J. Biol. Chem., 232, 1119 (1958)

11) Sawada, H., Takeshita, M., Sugita, Y. and Yoneyama, Y. : Bioch. Biophys. Acta, 178, 145 (1969)

12）浦田郡平, 暒本雅俊，鈴木妙子, 山田美恵子, 木 村秀子, 近藤雅雄, 佐々木教子, 小林克己 : 日米

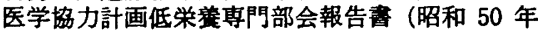
度), p. 67 (1975)

13) 丸田英夫 : 産業医学, 19, 167 (1977)

14) Adbulla, M., Svensson, S., Hager-Aronsen, B., Mathur, A. and Wallenius, K. : Enzyme, 23, 170 (1978)

15）浦田郡平，鈴木妙子，暒本雅俊，小林克己，千葉 省三, 浦部晶夫 : 生化学, 48, 695 (1976)

16) Abdulla, M. and Svensson, S. : Enzyme, 23, 164 (1978)

17) Labbe, R.F. and Finch, C.A. : Biochem. Med., 18,323 (1977)

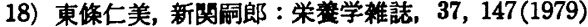

19）浦田郡平, 梶本雅俊, 鈴木妙子, 近藤雅婎, 木村 秀子，佐々木较子：日米医学協力計画栄異状専 門部会報告畫 (昭和53年度), p. 85 (1979)

20）佐々茂：日本臨床 (増刊号)，453，244 (1980)

21）浦田郡平, 木村秀子, 青木洋祐, 和田 攻 : 原子 力平和利用研究成果報告書 (科学技術庁)，2，270 (1972)

22）佐々 茂, 高久史應, 和田 攻, 中尾喜久：臨床 血液, 8, 181 (1967)

23）刏米重夫：日本臨床 (増刊号)，453，257 (1980) 
24) Bothwell, T.H., Charlton, R.W., Cook, J.D. and Finch, C.A. : Iron Metabolism in Man, p. 256 (1979), Blackwell Scientific Publications (London)

25) Ezyat, K.A. and Hegsted, D.M. : J. Nutr. 101, 927 (1971)

26) Dallman, P.R. : J. Nutr., 97, 475 (1969)

27) Viteri, Alvarado and Luthringer, Wood : Vitomin \& Horm., 26, 573 (1968)

28) Viart, P. : Am. J. Clin. Nutr., 30, 334 (1977)
29）新居美都子，和田 佐，石田元男 : 小览科診虔， 38,94 (1975)

30）近藤雅雄，椐本雅使，佐々木数子，丹羽源男，鉿 木妙子, 木村秀子, 浦田郡平: 中学における生 化学的フフ十ロ-チ (井村伸正他蹋集), p. 179 (1980), 篠原出版 (東京)

31）㭺本雅俊，長谷川菜子，鉿木妙子，近藤雅雄，木 村秀子, 丹羽源男, 浦田郡平 : 栄蓄と食㘿, 34, $43(1981)$

（昭和 55 年 8 月 14 日受理） 